\title{
Close Relationship
}

National Cancer Institute

\section{Source}

National Cancer Institute. Close Relationship. NCI Thesaurus. Code C89291.

A relationship bound by mutual interests or loyalties. 